\title{
Potential Roles of Essential Oils on Controlling Plant Pathogenic Bacteria Xanthomonas Species: A Review
}

\author{
Vivek K. Bajpai ${ }^{1}$, Sora Kang ${ }^{1}$, Houjuan $\mathrm{Xu}^{1,4}$, Soon-Gu Lee ${ }^{2}$, Kwang-Hyun Baek ${ }^{1 *}$ and Sun Chul Kang ${ }^{3 *}$ \\ ${ }^{\prime}$ School of Biotechnology, Yeungnam University, Gyeongsan, Gyeongbuk 712-749, Korea \\ ${ }^{2}$ School of Bioresource, Andong National University, Andong 760-749, Korea \\ ${ }^{3}$ Department of Biotechnology, Daegu University, Gyeongsan, Gyeongbuk 712-714, Korea \\ ${ }^{4}$ College of Plant Protection, Shandong Agricultural University, Tai-an 271-018, China \\ (Received on June 20, 2011; Revised on July 24, 2011; Accepted on July 24, 2011)
}

Diseases caused by plant pathogenic bacteria constitute an emerging threat to global food security. Xanthomonas is a large genus of Gram-negative bacteria that cause disease in several host plants leading to considerable losses in productivity and quality of harvests. Despite the ranges of controlling techniques available, the microbiological safety of economically important crops and crop plants including fruits and vegetables continues to be a major concern to the agriculture industry. On the other hand, many of the currently available antimicrobial agents for agriculture are highly toxic, non-biodegradable and cause extended environmental pollution. Besides, the use of antibiotics has provoked an increased resistance among the bacterial pathogens and their pathovars. Thus, novel efficient and safe remedies for controlling plant bacterial diseases are necessary. There has been an increasing interest worldwide on therapeutic values of natural products such as essential oils, hence the purpose of this review is to provide an overview of the published data on the antibacterial efficacy of essential oils that could be considered suitable for application in agriculture as biocontrol measures against plant pathogenic bacteria of Xanthomonas species. The current knowledge on the use of essential oils to control Xanthomonas bacteria in vitro and in vivo models has been discussed. A brief description on the legal aspects on the use of essential oils against bacterial pathogens has also been presented. Through this review, a mode of antibacterial action of essential oils along with their chemical nature and the area for future research have been thoroughly discussed.

\footnotetext{
*Corresponding author.

KH Baek

Phone) +82-53-810-3029, FAX) +82-53-810-4769

E-mail)khbaek@ynu.ac.kr

SC Kang

Phone) +82-53-850-6553, FAX) +82-53-850-6559

E-mail) sckang@daegu.ac.kr
}

Keywords : antibacterial effect, bacteria disease, essential oils, Xanthomonas species

Plants are constantly exposed and threatened by a variety of pathogenic microorganisms present in their environments. Plant diseases caused by pathogenic bacteria significantly contribute to the overall loss in crop yield worldwide (Montesinos, 2007; Savary et al., 2006). In an effort to combat diseases, plants have devised various mechanisms to fend off microbial invaders. Despite the existence of defense mechanisms, a major difficulty encountered is the lack of effective control against some severe diseases. The genus Xanthomonas in the gamma subdivision of the Proteobacteria consists of plant-associated species, many of which cause serious diseases of crops and vegetables including ornamentals. Individual species comprise multiple pathogenic variants (pathovars, pv.). Collectively, members of the genus cause disease on monocot and dicot species, including fruit and nut trees, solanaceous and brassicaceous plants, and cereals by affecting a variety of plant parts including leaves, stems, and fruits (Hayward, 1993). They cause a variety of symptoms including necrosis, cankers, spots, and blight (Leyns et al., 1984).

Bacterial diseases caused by Xanthomonas have devastated various host plants, leading to considerable losses in productivity and quality of the harvests (Cavalcanti et al., 2006; Ji et al., 2008). Pathovars of Xanthomonas are reported to have developed resistance to several antibiotics, such as kanamycin, ampicillin, penicillin and streptomycin (Rodriguez et al., 1997). Using metal derivatives for plant protection against pathovars of Xanthomonas serves as a potential threat to environment. Therefore, these limitations seriously hinder the management of diseases of crops and agricultural products (Dekker, 1987). Besides, control of the disease is difficult, often requiring expensive and complex integrated pest managements, which include the use of contamination-free seeds, sanitization practices and the use 
of chemicals (Araujo et al., 2003). Antibiotics and synthetic pesticides are forbidden in many countries because of their exerting negative impact such as high and acute toxicity, long degradation periods and accumulation in the food chain. Consequently, there is an obvious need to search for alternative natural antimicrobial agents or biopesticides, which can be nontoxic for disease control and nonpolluting environmentally to control plant diseases for agricultural applications and also have activity against pathogenic Xanthomonas bacteria that acquire resistance to commercial compounds (Franco et al., 2006).

Researches focused on plant-derived natural bactericides and their possible applications in agriculture to control plant bacterial diseases are being intensified as these are having enormous potential to inspire and influence modern agrochemical research. Naturally occurring and biologically active plant products such as essential oils could be a source of alternative classes of natural bio-pesticides to serve as templates for new and more effective compounds in controlling plant pathogenic microorganisms. Bio-pesticides have also been suggested as effective substitutes for chemical pesticides (Gan-Mor and Matthews, 2003).

Essential oils, the odorous and volatile products of an aromatic plant's secondary metabolism, normally formed in special cells or groups of cells, are well-known antimicrobial agents that could be used to control plant pathogenic bacteria of Xanthomonas species in agriculture (Bajpai et al., 2010a, b; Nguefack et al., 2005). They have long been served as flavouring agents in food and beverages, and due to their versatile content of antimicrobial compounds, they possess potential as natural agents for plant protection in agriculture industry. Chemical analysis of the essential oils has revealed the presence of several ingredients, most of which posses important antimicrobial properties (Bajpai et al., 2007; Bajpai et al., 2010a, b; Nguefack et al., 2005). Several references on the antimicrobial efficiency of essential oils are available in the literature (Burt and Reinders, 2003; Cox et al., 2000; Delaquis et al., 2002; Gyorgyi et al., 2004; Mejholm and Dalgaard, 2002; Nguefack et al., 2005). More particularly, essential oils and their components are known to be active against a wide variety of microorganisms, including Gram-negative (Helander et al., 1998) and Gram-positive bacteria (Kim et al., 1995). Although, a small number of essential oils are commercially available, very few studies of the activity of essential oils against Xanthomonas bacteria have been published. Moreover, it has been established that, certain essential oils stand out as better antibacterial agents than the commonly used chemical antibacterial agents against plant pathogenic bacteria of Xanthomonas species (Bajpai et al., 2010a, b; Gyorgyi et al., 2004; Nguefack et al., 2005). Applications of several essential oils in agriculture have been found effective in inhibiting the growth of Xanthomonas bacteria (Bajpai et al., 2010a, b; Gyorgyi et al., 2004; Nguefack et al., 2005). Hence, to reduce health hazards and economic losses due to plant pathogenic Xanthomonas bacteria, the use of essential oils as natural antibacterial compounds seem to be an interesting way to control the presence of plant pathogenic bacteria in agriculture.

The antimicrobial activity of essential oils is assigned to a number of small terpenoids and phenolic compounds (thymol, carvacrol, eugenol), which also in pure forms were demonstrated to have high antibacterial activity (Conner, 1993; Didry et al., 1993; Gyorgyi et al., 2004). A number of essential oil constituents exhibit significant antimicrobial properties when tested separately (Gyorgyi et al., 2004; Kim et al., 1995; Lambert et al., 2001). However, there are evidences that essential oils are more strongly antimicrobial than are accounted for by the additive effect of their major antimicrobial components; minor components appear, therefore, to play a significant role (Paster et al., 1995). There are often large differences in the reported antimicrobial activity of essential oils from the same plant sources. The reasons of this variability can be traced back to the differences in the plant origins for the oils by geographical distributions, the harvesting seasons, the genotypes, the drying procedure and the distilled parts of the plant. All of this variability can influence the chemical composition and the relative concentration of each constituent in the essential oils (Salgueiro et al., 1997).

Recently, there has been a considerable interest in essential oils from common culinary herbs, spices and aromatic plants characterized by a notable antimicrobial activity (Gyorgyi et al., 2004; Nguefack et al., 2005; Tobias et al., 2007). Such oils can be used to inhibit the growth of plant pathogenic bacteria in an agricultural system (Bajpai et al., $2010 \mathrm{a}, \mathrm{b}$ ). This growing interest is emphasized by the fact that diseases caused by plant pathogenic bacteria of Xanthomonas species are still a major problem in the world, even in well developed countries (McManus et al., 2002). In such context, plant essential oils are well known to exhibit a wide range of biological activities as well as they tend to have low mammalian toxicity, less environmental detrimental effects and wide public acceptance (Paranagama et al., 2003). Hence, they form the basis of many applications in food and agriculture industries to control plant pathogenic bacteria of Xanthomonas species.

\section{Pathogen Biology}

The taxonomy of plant pathogenic bacteria is currently in flux based on recent advances on how bacteria are classified. Most plant pathogenic bacteria belong to the following genera: Pectobacterium, Pantoea, Agrobacterium, Pseudo- 
monas, Ralstonia, Burkholderia, Acidovorax, Xanthomonas, Clavibacter, Streptomyces, Xylella, Spiroplasma, and Phytoplasma. Plant pathogenic bacteria cause many different kinds of symptoms that include galls and overgrowths, wilts, leaf spots, specks and blights, soft rots, as well as scabs and cankers. The Xanthomonas bacteria are the names of the pathogens that have led to the loss of many crops in Asia, America and many other hot and humid areas. They attack important cultivated plants such as rice, peppers, beans, melons, grapes, cotton, tomatoes and citrus fruits by manipulating the genes of these plants. Other ornamental plants infected by $X$. campestris pv. dieffenbachiae include Chinese evergreen, Silver Queen and other Aglaonema species, fancy-leaved caladiums (Caladium species.), and cocoyam (X. caracu). Xanthomonas bacteria cause their effects on the plants by producing large amounts of polysaccharides that block the xylem vessels carrying water through the plants. For large scale production, the bacteria are grown in culture to obtain these polysaccharides, better known as xanthan gum, a thickener used in the food industry. Bacteria of Xanthomonas species that cause plant diseases are spread in many ways; they can be splashed about by rains or carried by the wind, birds, or on insects. People can unwittingly spread bacterial diseases by, for instance, pruning infected orchard trees during the rainy season. Water facilitates the entrance of bacteria carried on pruning tools into the pruning cuts. Propagation with bacteria-infected plant material is a major way pathogenic bacteria are moved over great distances. No matter how the bacterial pathogens are disseminated, they require a wound or natural opening, such as stomata, to get inside a plant host. Once inside they then kill host cells, by the means describe above, so that they can grow. Between hosts they may grow harmlessly on plant surfaces and then can over winter or survive unfavourable environmental periods or the absence of a susceptible host by either going dormant in infected tissue, infested soil or water, or in an insect vector.

Bacteria cannot enter plants via intact cuticles, and entry is either through wounds or natural openings such as hydathodes and stomata (Manners, 1993). There are so many different species of Xanthomonas bacteria such as $X$. albilineans, $X$. arboricola sp., X. axonopodis sp., X. bromi, $X$. campestris spp., $X$. cassavae, $X$. citri, $X$. codiaei, $X$. cucurbitae, $X$. cynarae, $X$. fragariae, $X$. gardneri, $X$. hortorum, $X$. hyacinthi, $X$. melonis, $X$. oryzae sp., $X$. pisi, $X$. populi, $X$. sacchari, $X$. theicola, $X$. translucens sp., $X$. vasicola, $X$. vesicatoria and $X$. spp. $X$. campestris pv. campestris enters to Arabidopsis thaliana leaves through hydathodes (Hugouvieux et al., 1998), which affects plants from the Brassica and Arabidopsis groups causing black rot. The disease symptoms progress from discolored leaves to extensive wilting of all of the stems and leaves, with all the leaves eventually turning yellow. Parts of the plant start to die and rot and the plant dies completely shortly afterwards. With regard to $X$. campestris pv. musacearum, mechanical damage as an entrance for initiation of enset bacterial wilt disease was demonstrated by cutting enset (Ensete ventricosum) leaves, a false banana with contaminated knives (ARCP, 2000; Dereje, 1985). Enset (E. ventricosum) is one of the indigenous root crops widely cultivated for its food and fiber values in Ethiopia and more than 15 million of Ethiopia's population depends on enset. Once the bacteria enter into the plant, they multiply in the intercellular spaces and move through the tissues. Cell death of the plant may follow due to toxins or pectolytic enzymes produced by the bacteria. In general the rate of spread of the disease depends on the rate of multiplication of the pathogen, its motility, its ability to produce pectolytic enzymes and the structure of the host. All the parameters are also affected by the environmental conditions especially on temperature and on the extent to which the host produces stimulants or inhibitors for bacterial growth and activity (Manners, 1993).

Based on the distribution and the damage incurred on enset production, enset bacterial wilt disease caused by $X$. campestris pv. musacearum is known to be the most threatening and important problem to enset production. However in banana, the disease is transmitted from infected plants to healthy plants by mechanical means mainly through implements used in enset cultivation (Dagnachew and Bradbury (1968). Other than enset (false banana), the disease affects banana under natural condition and epidemics of the disease was reported in the former Kaffa province (Dagnachew and Bradbury, 1974). Wilt symptoms were observed in banana through artificial inoculation of the disease (Dereje, 1985), and recently a screening trial on banana cultivars for resistance to enset bacterial wilt disease revealed that all cultivars were found susceptible to enset bacterial wilt (ARCP, 2000). However, Dagnachew and Bradbury (1968) inoculated 27 plant species other than enset and banana and all failed to develop the symptom. On the other hand, Dereje (1981) inoculated 11 plant species and disease symptoms were observed only on Canna orchoides, which does not belong to Musaceae family.

Surveys conducted in the early 1980's and 1990's in major enset growing zones revealed the occurrence of enset bacterial wilt disease in all zones with different degree of severity (Dereje, 1985; Spring et al., 1996). It was very destructive as it killed enset plants at all growth stages including 4 to 7 years old plants ready to be harvested (Quimio and Mesfin, 1996). Once it appears in a field, it is easily transmitted from infected enset plants to healthy plants through different mechanisms and in some areas where the severity of the disease and loss is high, farmers 
are obliged to abandon the whole field and replace it with another crop.

On the other hand, the disease could be disseminated with agents like wind and rain (Agrios, 2004) as the ooze like exudates from the bacteria filling the parenchyma tissues of the enset easily flow out from infected plants to healthy ones. Contaminated soil and infected debris are also possible dissemination agents as survival studies on other $X$. campestris pathovars in soil and plant debris strengthened the possibility. For example, according to the study of Thaveechai et al. (1993), survival of populations of $X$. campestris pv. manihotis strain CSg in plant tissue and soil samples were evaluated by using semi-selective media and they were found to survive for one to two weeks in rhizosphere soil of cassava weeds and for three to seven weeks in infected cassava tissues buried in the soil. Hence, it was suggested that cassava debris may be important as a source of inoculum than rhizosphere soil of weeds for the dissemination of cassava bacterial blight. $X$. campestris pv. glycine were also remained viable for 110 days in infected soybean leaves placed on soil surface and for 29 days in infected leaves buried deep 15 centimetres (Khare and Khare, 1995).

\section{Detection of Genetic Variation}

Accurate strain identification of pathogens is important for epidemiological and ecological monitoring purposes where highly refined genetic technologies facilitate high-resolution distinctions (Gabriel and De Feyter, 1992). The availability of powerful analytical tools such as DNA sequencing, DNA-DNA hybridization, multi loci isozyme analysis and restriction fragment length polymorphism (RFLP) hybridization analysis are influencing changes towards phylogenetic based taxonomies. In recent time, rep-PCR is becoming an important tool to measure the genetic variations among the bacterial strains. The technique was used to differentiate pathovars and strains of Xanthomonads. This technique was based on the amplification of DNA with oligonucleotide primers from three families of unrelated repetitive sequences corresponding to repetitive extragenic palindromic (REP), enterobacterial repetitive intergenic consensus (ERIC) and BOX elements (Veracruz et al., 1996). The primers amplify DNA between the dispersed elements and these fragments are likely to be different in size so that differences between closely related strains might be detected. The variation detected by each primer usually differs. For example, in measurement of haplotypic variation in $X$. oryzae pv. oryzae, ERIC primers resulted in the most consistent group of bacterial strains and remained easiest to recognize visually followed by REP and BOX the least (Veracruz et al., 1996). The combined analyses of the yields from the three primers including yields from RFLP could give refined groups of strains (Veracruz et al., 1996).

Phenotypic and genetic variations were observed in different $X$. campestris pathovars. For instance, biochemical and pathogenic variations were observed in bacterial strains of $X$. campestris pv. mangiferaindicae collected from southern India. The isolates were different in their ability to liquefy gelatin, reduce nitrate and utilize carbon sources (Dayakar and Gnanamanickam, 1996). Pathogenic variability was also observed in isolates of $X$. campestris pv. glycines collected from soybean cultivars from six states of USA and National Collection of Plant Pathogenic Bacteria in England. Based on the variability in pathogenicity, the isolates were classified into five races among which some avirulent strains were found (Hwang et al., 1998). Phenotypically distinct strains of $X$. campestris pv. mangiferaeindicae as yellow pigmented and apigmented were isolated in Brazil (Pruvost et al., 1998). White pathovars of X. campestris were also observed (Sugimori and Oliveira, 1994). Genetic variations in different isolates of several $X$. campestris pathovars have also been observed and measured using different molecular techniques such as RFLP and repPCR (Norman et al., 1999; Restrepo et al., 2000).

\section{Chemical and Biological Control Measures}

Bacterial diseases in plants are difficult to control. Emphasis is on preventing the spread of the bacteria rather than on curing the plant. Integrated management measures for bacterial plant pathogens include chemical and biological measurements. So far no bactericide has been recommended against enset bacterial wilt. Various in vitro trials were done on antibiotics and plant extracts against $X$. campestris pathovars that cause diseases in different crops. For example, streptomycin, oxytetracycline, chloroamphenicol and rifampicin were tested for the control of black rot of cauliflower caused by $X$. campestris pv. campestris and streptomycin was the most effective, giving $100 \%$ control followed by oxytetracycline (Lenka and Ram, 1997). In vitro test was also done on $X$. campestris pv. mangiferaeindicae and all the chemicals and antibiotics used, aureofungin, bavistin, erythromycin, streptocycline, streptomycin and tetracycline inhibited the bacterium (Talwar et al., 1996). Efficiency of copper oxychloride and a mixture of oxytetracycline + streptomycin sulfate were also evaluated in controlling angular leaf spot of cotton caused by $X$. campestris pv. malvacearum in fields and $643.3 \mathrm{~g} / \mathrm{ha}$ oxytetracycline + streptomycin sulfate solution was recommended to control the disease severity (Araujo and Siqueri, 1999). Nisin at $50 \mu \mathrm{g} / \mathrm{ml}$ concentration also reduced the growth of $X$. campestris pv. campestris by greater than $90 \%$ 
(Wells et al., 1998).

In addition to this, several other studies have indicated the potential of plant extracts in the control of diseases caused by $X$. campestris in important crop plants. When 208 diffusates from various plants such as forest trees, shrubs, herbs and fruit seeds were tested against $X$. campestris pv. citri, diffusates (50 g/liter) from various parts of Phyllanthus emblica, Acacia nilotica, Sapindus mukorossis and Terminalia chebula appeared to be the most effective against the pathogen (Akhtar et al., 1995). Extracts from Acacia arabica, Achras zapota, and from other six higher plants were also found inhibitory to various pathovars of $X$. campestris (Satish et al., 1999). Chamomilla recutita and Chamaemelum nobile extracts also inhibited the growth of $X$. campestris pv. citri strains causing citrus bacterial canker disease (Csizinszky et al., 1993). Medicinal and aromatic plants Azadirachta indica and Ipomoea carnea extracts were found effective at reducing the incidence and intensity of the cotton bacterial blight infection (Patil and Ghoderao, 1997). Root and leaf extracts of Adhatoda zeylanica showed in vitro inhibition of $X$. campestris pv. vignicola (Thammaiah et al., 1995). The in vivo antibacterial effects of the natural substances contained in the Allium sativum and Ficus carica extracts were identified on tomato plants inoculated with bacterial suspension of $X$. vesicatoria at $10^{5} \mathrm{cfu} / \mathrm{ml}$ (Balestra et al., 2009). A. sativum extract reduced disease incidence caused by $X$. vesicatoria which resulted in 22 diseased leaflets per plant. Considering the untreated control value of 38 diseased leaflets per plant, the maximal reduction of up to $56 \%$ of disease incidence was achieved by $A$. sativum extract on plants inoculated with $X$. vesicatoria. Treatments with $F$. carica fruit extracts were less effective compared to those treated with A. sativum (Balestra et al., 2009).

Applications of copper-containing compounds or Bordeaux mixture (copper sulfate and lime) and antibiotics (streptomycin and/or oxytetracycline) may also help to kill or suppress plant pathogenic bacteria prior to infection and reduce spread of the disease, but they will not cure plants that are already diseased. Antibiotics are also used to treat diseases caused by fastidious vascular bacteria. Tetracycline must be injected into mature trees on a routine or therapeutic schedule to be effective and even then only appears to suppress the development of symptoms rather than curing the infected plant. Applications made during the early stages of infection tend to be more effective than in the later stages of disease development. Although chemical control measures are available, the pathovars of Xanthomonas are reported to have developed resistance to several antibiotics (Rodriguez et al., 1997).

A biological control efficacy of Bacillus strains B. cereus, $B$. lentimorbus and B. pumilus was evaluated against $X$. campestris pv. campestris on cabbage and the influence of the method applied was demonstrated as biological control measures. The incidence and severity of Xanthomonas black rot in the foliage, stems and heads of the highly susceptible cultivar, Copenhagen Market, were significantly reduced, especially when antagonists were applied through the roots as compared to application through the seeds or foliage (Massomo et al., 2004).

As described previously, under field conditions, four weekly applications of acibenzolar-S-methyl reduced severity of Xanthomonas leaf blight as or more effectively than 9 to 12 weekly applications of copper hydroxide or copper hydroxide-mancozeb (Gent and Schwartz, 2005).

Acibenzolar-S-methyl applications did not increase bulb yield or grade compared with copper bactericide treatments. However, bulb yield was reduced 22 to $27 \%$ when 10 weekly applications of acibenzolar- $S$-methyl were made in the absence of disease. Application of a commercial formulation of both Pantoea agglomerans and Pseudomonas fluorescens reduced severity of Xanthomonas leaf blight in field experiments. Weekly copper hydroxide applications starting 1 to 2 weeks before bulb initiation were as effective as weekly applications started 3 to 4 weeks before bulb initiation, irrespective of the maneb rate used. Integration of acibenzolar-S-methyl and biological control agents with copper hydroxide in a carefully timed spray program may eliminate the use of the class B2 carcinogens maneb and mancozeb on onion without compromising efficacy for management of Xanthomonas leaf blight (Gent and Schwartz, 2005).

\section{Control of Xanthomonas Bacteria by Essential oils, Plant-based Natural Antimicrobials}

In spite of modern improvements, the agriculture production incurs yearly losses because of plant diseases caused by plant pathogens. Control of plant bacterial diseases remains difficult due to the limited availability of bactericides and the ability of a large number of phytopathogenic bacteria to spread (Claflin, 2003). Only a few chemical products are available, and their use is hampered by limited efficacy in the field but mainly for their potential negative effects either in the environment or with human and animal health. Besides the antibiotic and copper compounds, which to some extent present undesirable attributes for either human and animal health or the environment, no other active compounds are available for controlling bacterial plant diseases. Furthermore, antibiotics oxytetracycline and streptomycin, used on plants in United States (McManus et al., 2002), are actually forbidden in the agricultural practices in many European countries to avoid the possible selection of individuals resistant to the drugs and hence the possible 
horizontal genetic transfer to animal and human pathogens. The control of plant bacterial diseases remains difficult due to the limited availability of bactericides. Besides, herbicides at high concentrations can also increase the risk of toxic residues in agricultural products. The use of copper compounds, which are widely used for the control of plant bacterial diseases, will be limited in the European Union countries by rule $473 / 2002$ due to their impact on the environment. As a consequence, measures to control plant bacterial diseases are mostly limited to prevention. The request of a reduction in the use of the pesticides in agriculture prompts the need for the development of alternative active compounds, possibly harmless to the consumers and to the environment and useful for the protection of crops for the control of plant bacterial diseases to be used in integrated crop management (Maiti et al., 1985; Maruzzella et al., 1963). The availability of new and eco-compatible bactericides may be very useful for bacterial control of diseases in the field trials.

Essential oils are known for their antimicrobial capability and have the potential to control plant diseases caused by bacteria. Essential oils are aromatic oily liquids obtained from plant material such as flowers, buds, seeds, leaves, twigs, bark, herbs, wood, fruits and roots (Guenther, 1948). They can be obtained by expression, but the method of steam distillation is most commonly used for commercial production of essential oils (Van de Braak and Leijten, 1999).

\section{Essential oils.}

An overview: An estimated 3,000 essential oils are known, many of which are commercially important-destined chiefly for the flavours and fragrances market (Van de Braak and Leijten, 1999). It has been well recognized that most of the essential oils have antimicrobial properties (Boyle, 1955; Carson and Riley, 1995; Deans and Ritchie, 1987; Guenther, 1948; Mourey and Canillac, 2002; Shelef, 1983). These characteristics are possibly related to the function of the compounds present in plants (Guenther, 1948; Mahmoud and Croteau, 2002).

The European Union has greatly employed the use of essential oils in foods (as flavourings), perfumes (fragrances and aftershaves) and pharmaceuticals (for their functional properties) (Bauer and Garbe, 1985; Van de Braak and Leijten, 1999; Van Welie, 1997). Individual components of essential oils are also used as food flavorings, either extracted from plant material or synthetically manufactured (Oosterhaven et al., 1995). The antibacterial properties of essential oils and their components have been exploited in diverse commercial products as a feed supplements (Ilsley et al., 2002; Van Krimpen and Binnendijk, 2001).

Many important food and crop products are perishable and require protection from microbial spoilage during their shelf-life. Traditional food preservation techniques alone cannot ensure the quality and safety of all food or agricultural products, and alternative preservation techniques, such as vapour phase and aroma-based techniques are being applied or investigated for their antibacterial or disease controlling potential (Isman, 2010; Lopez et al., 2005).

Nevertheless, food processors and consumers have expressed a desire to reduce the use of both aggressive techniques and synthetic chemicals in food and agro products, mainly because the presence of chemical residues in foods and labelling of preservatives in food packages are major concerns nowadays. Therefore, there is a clear need for new methods of protecting important crop plants or food products using natural additives, and a very interesting option is the use of essential oils as natural antimicrobials, because they are rich sources of biologically active compounds.

The antimicrobial activity of essential oils has been extensively studied and demonstrated against a number of microorganisms, and usually using a direct-contact antimicrobial assay. In these tests, essential oils are brought into contact with the selected microorganisms, and their inhibition is monitored by means of direct inspection or by measuring a physical property that is directly related with microorganism growth, such as optical density, impedance, or conductance (Angioni et al., 2004; Burt, 2004; Holley and Patel, 2005). Nevertheless, there is still an underlying assumption that essential oils are to be added to the foodstuff per se rather than to the packaging, and even if they are added to the packaging, they will exert their effects solely via direct contact, rather than via the volatiles in the vapour phase, which may not always be the case. There is a general lack of scientific information concerning the antimicrobial effectiveness of essential oils in the vapour phase compared with direct contact, although some degree of inhibition by volatile components of essential oils has been demonstrated (Caccioni et al., 1998).

It is also potentially interesting to correlate the composition of the atmosphere generated by essential oils with their antimicrobial behavior. Solid-phase micro extraction is a convenient and completely solvent-free technique in which a small fused silica fiber with a polymeric coating is used to extract analytes from sample matrices. These methods have been developed for a wide range of vapor-monitoring applications, and they can be regarded as passive and diffusive sampling methods (Batlle et al., 2001; Chen and Pawliszyn, 2003), thus avoiding the need for the air-sampling pumps or aspirators that are typically used in dynamic or active methods.

The antimicrobial activity of essential oils of cinnamon, clove, basil, rosemary, dill, and ginger was reported over a 
range of concentrations in solid and vapor diffusion assays (Lopez et al., 2005). Differences among the volatiles in the essential oils, which may be responsible for the differences in their antimicrobial performances against an array of Gram-positive and Gram-negative bacteria, were found. The lower susceptibility of Gram-negative bacteria may be due to the distinctive properties of its outer membrane (Longbottom et al., 2004). Gram-negative strains are generally more resistant than Gram-positive strains, and this trait has been attributed to the external lipopolysaccharide wall that surrounds the peptidoglycan cell wall of Gram-negative bacteria. However, this does not seem to be a major factor in vapor-phase inhibition, because there were no significant differences overall in inhibition between Gram-positive and Gram-negative bacteria in the vapor phase tests.

Chemistry of essential oils. Essential oils are complex mixtures of volatile constituents which are bio-synthesized by living organisms. Essential oils can be liberated from their matrix by water, steam and dry distillation, or expression (Bajpai et al., 2007). Their occurrence and function in nature are still questions and the subject of ongoing research. Essential oils may comprise volatile compounds of terpenoid or non-terpenoid origin. All of them are hydrocarbons and their oxygenated derivatives (Bajpai et al., 2007). Some may also contain nitrogen or sulphur derivatives (Miyazawa et al., 2002). They may exist in the form of alcohols, acids, esters, epoxides, aldehydes, ketones, amines and sulphides etc. Monoterpenes, sesquiterpenes and even diterpenes constitute the composition of most of the essential oils. In addition, phenylpropanoids, fatty acids and their esters, or their decomposition products are also encounterd as volatiles. The components of essential oils include two groups of distinct biosynthetical origin (Pichersky et al., 2006). The main group is composed of terpenes and terpenoids, and the other of aromatic and aliphatic constituents.

Terpenes are widespread in nature, mainly in plants as constituents of essential oils as structurally and functionally different classes. They are made from combinations of several 5-carbon-base (C5) units called isoprene, $\mathrm{CH}_{2}=$ $\mathrm{C}\left(\mathrm{CH}_{3}\right)-\mathrm{CH}=\mathrm{CH}_{2}$. Terpene hydrocarbons therefore have molecular formulas $\left(\mathrm{C}_{5} \mathrm{H}_{8}\right)_{\mathrm{n}}$, they are classified according to the number of isoprene units: monoterpenes $(\mathrm{C} 10,2$ isoprene units), sesquiterpenes (C15, 3 isoprene units), diterpenes (C20, 4 isoprene units), triterpenes (C30, 6 isoprene units), and tetraterpenes (C40, 8 isoprene units). The biosynthesis of the terpenes consists of synthesis of the isopentenyl diphosphate precursor, repetitive addition of isopentenyl diphosphates to form the prenyldiphosphate precursor of the various classes of terpenes, modification of the allylic prenyldiphosphate by terpene specific synthetases to form the terpene skeleton and finally, secondary enzymatic modification of the skeleton to attribute functional properties to the different terpenes. The main terpenes are the monoterpenes and sesquiterpenes. Many terpenes are hydrocarbons, but oxygen-containing compounds such as alcohols, aldehydes or ketones are called terpenoids.

The monoterpenes are formed from the coupling of two isoprene units. They are the most representative molecules constituting $90 \%$ of the essential oils and allow a great variety of structures. Following chemical classes are included as monoterpenes such as carbures, alcohols, aldehydes, ketones, esters, ethers, peroxydes and phenols. The sesquiterpenes are formed from the assembly of three isoprene units. The extension of the chain increases the number of cyclizations which allows a great variety of structures. The structure and function of the sesquiterpenes are similar to those of the monoterpenes which also include carbures, alcohols, ketones and epoxide.

The aromatic compounds derived from phenylpropane, occur less frequently than the terpenes. The biosynthetic pathways concerning terpenes and phenylpropanic derivatives generally are separated in plants but may coexist in some, with one major pathway taking over. Aromatic compounds include aldehyde, alcohol, phenols, methoxy derivatives and ethylene dioxy compounds. Nitrogenous or sulphured components such as glucosinolates or isothiocyanate derivatives are also characterized as the secondary products of several essential oils. A list of selected plantbased antimicrobial essential oil components has been given in Fig. 1.

Mechanism of action of essential oils. Although antibacterial efficacy of essential oils has been reviewed extensively, the mechanism of action has not been studied in great detail (Lambert et al., 2001). Considering the large number of different groups of chemical compounds present in essential oils, it is most likely that their antibacterial activity is not attributable to one specific mechanism but that there are several targets in the cell (Carson et al., 2002; Skandamis and Nychas, 2001). Not all of these mechanisms are separate targets; some are affected as a consequence of another mechanism being targeted. An important characteristic of essential oils and their components is their hydrophobicity, which enables them to partition in the lipids of the bacterial cell membrane and mitochondria, disturbing the structures and rendering them more permeable (Knobloch et al., 1986; Sikkema et al., 1995). Leakage of ions and other cell contents can then occur (Gustafson et al., 1998; Helander et al., 1998; Cox et al., 2000; Lambert et al., 2001). Although a certain amount of leakage from bacterial cells may be tolerated without loss of viability, extensive loss of cell contents or the exit of critical mole- 


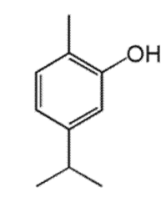

Carvacrol

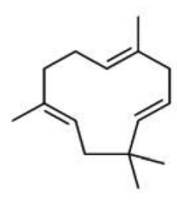

Humulene

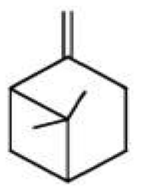

2- $\beta$-pinene<smiles>CC(C)=CCCC(C)=CCO</smiles>

Geraniol<smiles>O=C/C=C/c1ccccc1</smiles>

Cinnamaldehyde<smiles>CC1CCC=C2CC[C@@H](C(C)(C)O)C[C@]21C</smiles>

Valerianol

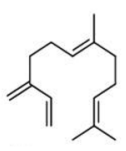

$\beta$-farnesene<smiles>C=CCc1ccc(O)c(OC)c1</smiles>

Eugenol

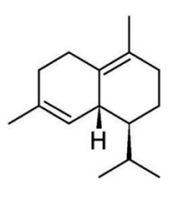

$\delta$-cadinene

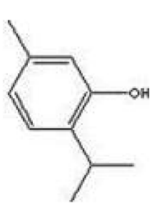

Thymol

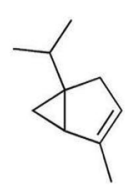

$\alpha$-thujene

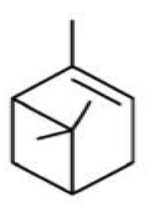

$\alpha$-pinene

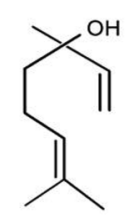

Linalool

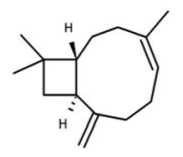

$\beta$-caryophyllene

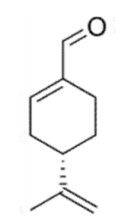

Perillaldehyde

Fig. 1. Chemical structures of some selected antimicrobial components of plant essential oils.

cules and ions will lead to death (Denyer and Hugo, 1991). Generally, the essential oils possessing the strongest antibacterial properties contain a high percentage of phenolic compounds such as carvacrol, eugenol (2-methoxy-4-(2propenyl) phenol) and thymol (Farag et al., 1989; Juliano et al., 2000; Lambert et al., 2001). It seems reasonable that their mechanism of action would therefore be similar to other phenolics; this is generally considered to be the disturbance of the cytoplasmic membrane, disrupting the proton motive force, electron flow, active transport and coagulation of cell contents (Sikkema et al., 1995). The chemical structure of the individual essential oil components affects their precise mode of action and antibacterial activity (Dorman and Deans, 2000). The importance of the presence of the hydroxyl group in phenolic compounds such as carvacrol and thymol has been confirmed (Dorman and Deans, 2000; Ultee et al., 2002). However, in one study carvacrol and thymol were found to act differently against Gram-positive and Gram-negative species (Dorman and Deans, 2000). The significance of the phenolic ring itself is demonstrated by the lack of activity of menthol compared to carvacrol (Ultee et al., 2002). In one study, the addition of an acetate moiety to the molecule appeared to increase the antibacterial activity; geranyl acetate was more active against a range of Gram-positive and negative species than geraniol (Dorman and Deans, 2000). Certainly, there are morphological changes that are apparent. The outer membrane of Gram-negative bacteria disintegrated following exposure to essential oil components (Helander et al., 1998) and major thickening and disruption of the cell wall, together with increased roughness and lack of cytoplasm have recently been reported in Xanthomonas pathogens on treatment with Metasequoia essential oil (Bajpai et al., 2010b; Rasooli et al., 2006). Components of essential oils also appear to act on cell proteins embedded in the cytoplasmic membrane (Knobloch et al., 1989). Enzymes such as ATPases are known to be located in the cytoplasmic membrane and to be bordered by lipid molecules. Two possible mechanisms have been suggested whereby cyclic hydrocarbons could act on these. Lipophilic hydrocarbon molecules could accumulate in the lipid bilayer and distort the lipid-protein interaction; alternatively, direct interaction of the lipophilic compounds with hydrophobic parts of the protein is possible (Juven et al., 1994; Sikkema et al., 1995). Cinnamon oil and its components have been shown to inhibit amino acid decarboxylases in Gram-negative bacterium (Wendakoon and Sakaguchi, 1995).

In addition to this, terpenes have the ability to disrupt and penetrate the lipid structure of the cell wall as well as cell membrane of bacteria leading to denaturing of proteins and destruction of cell membrane leading to cytoplasmic leakage, cell lysis and eventually cell death. The decrease in $\mathrm{pH}$ that occurs due to this cell membrane disruption means that control of cellular processes such as DNA transcription, protein synthesis and enzyme activity is lost (Raybaudi-Massilis et al., 2006; Oussalah et al., 2006).

Antibacterial Efficacy of Essential Oils In Vitro and In Vivo. The increasing social and economic implications caused by plant pathogenic bacteria means there is a 
constant striving to produce safe and diseases-free foods (crops, vegetables and fruits) and to develop safe and natural antibacterial agents of a plant origin. In general, plant-derived essential oils are considered as nonphytotoxic compounds and potentially effective against various plant pathogenic bacteria (Basim and Basim 2003; Vasinauskiene et al., 2006). In recent years, the use of antimicrobial compounds such as essential oils is one of the first choices after outbreaks of bacterial plant diseases (Ornek et al., 2007). Interest has been generated in the development of safer antibacterial agents to control plant pathogenic bacteria in agriculture which also include essential oils (Nguefack et al., 2005; Ozturk and Ercisli, 2007).

Essential oils, which are odorous and volatile products of plant secondary metabolism, have wide applications in controlling plant pathogenic bacteria (Ozturk and Ercisli, 2007). Recently we reported the in vitro antibacterial efficacy of essential oils derived from the cones of $M$. glyptostroboides and $C$. operculatus buds which were quantitatively assessed against plant pathogenic bacteria of Xanthomonas species, such as $X$. campestris pv. campestris KC94-17-XCC, X. campestris pv. vesicatoria YK93-4-
XCV, X. oryzae pv. oryzae KX019-XCO and X. sp. SK12 (Bajpai et al., 2010a, b). The chemical compositions of the essential oils were identified in the cones of $M$. glyptostroboides and C. operculatus buds (Bajpai et al. 2007; Dung et al., 2008) and the oils contained mono- and sesquiterpenes and their hydrocarbons, as earlier reported the major or minor components of the various essential oils, which have enormous potential to inhibit pathogenic microbes including plant pathogenic bacteria (Basim and Basim, 2003; Satish et al., 1999; Morris et al., 1979; Vasinauskiene et al., 2006). An overview of the literature data on the in vitro antibacterial efficacy as minimum inhibitory concentration (MIC) and minimum bactericidal concentration (MBC) values of various plant-based essential oils against plant pathogenic Xanthomonas species is presented in Table 1.

The antibacterial efficacy of essential oils form four thyme chemotypes Thymus vulgaris, T. serpyllum, T. citriodorus and $T$. citriodorus and their main components such as thymol, geraniol and carvacrol held a controlling effect against Gram-negative plant pathogenic bacteria by the direct bioautography method (Gyorgyi et al., 2004). All the treatments displayed potent inhibitory effect against the

Table 1. MIC and MBC of selected plant essential oils against plant pathogenic bacteria of Xanthomonas species

\begin{tabular}{|c|c|c|c|c|}
\hline EO derived from & Bacteria & MIC & $\mathrm{MBC}$ & Reference \\
\hline Tanacetum chiliophyllum & X. axanopodis pv. malvecearum & $166.7 \mu \mathrm{l} / \mathrm{ml}$ & - & Salamci et al., 2007 \\
\hline Tanacetum aucheranum & X. axanopodis pv. malvecearum & $55.4 \mu \mathrm{l} / \mathrm{ml}$ & - & Salamci et al., 2007 \\
\hline Thymus spathulifolius & X. campestris-A235 & $500 \mu \mathrm{g} / \mathrm{ml}$ & - & Sokmen et al., 2004 \\
\hline Lantana camara & $X$. campestris & $1: 0 ; 1: 1 ; 1: 2$ (EO + acetone) & - & Deena and Thoppil, 2000 \\
\hline \multirow{3}{*}{ Rosa damascene } & X. vesicatoria XV88-5 & $1,500 \mu \mathrm{g} / \mathrm{ml}$ & - & Basim and Basim, 2003 \\
\hline & X. vesicatoria XV56 & $1,500 \mu \mathrm{g} / \mathrm{ml}$ & - & Basim and Basim, 2003 \\
\hline & X. vesicatoria XV97-2 & $1,500 \mu \mathrm{g} / \mathrm{ml}$ & - & Basim and Basim, 2003 \\
\hline Salvia verticillata & X. axonopodis pv. vesicatoria & $100 \mu \mathrm{l} / \mathrm{ml}$ & - & Kotan et al., 2007 \\
\hline Teucrium chamaedrys & X. axonopodis pv. vesicatoria & $800 \mu \mathrm{l} / \mathrm{ml}$ & - & Kotan et al., 2007 \\
\hline Artemisia absinthium & X. axonopodis pv. vesicatoria & $100 \mu \mathrm{l} / \mathrm{ml}$ & - & Kotan et al., 2007 \\
\hline Tanacetum aucheranum & X. axanopodis pv. malvecearum & $55.4 \mu \mathrm{l} / \mathrm{ml}$ & - & Salamci et al., 2007 \\
\hline Tanacetum chiliophyllum & X. axanopodis pv. malvecearum & $166.7 \mu \mathrm{l} / \mathrm{ml}$ & - & Salamci et al., 2007 \\
\hline Salvia pratensis & X. axonopodis pv. vesicatoria & $200 \mu \mathrm{l} / \mathrm{ml}$ & - & Kotan et al., 2007 \\
\hline Teucrium polium & X. axonopodis pv. vesicatoria & $600 \mu \mathrm{l} / \mathrm{ml}$ & - & Kotan et al., 2007 \\
\hline Achillea biebersteini & X. axonopodis pv. vesicatoria & $50 \mu \mathrm{l} / \mathrm{ml}$ & - & Kotan et al., 2007 \\
\hline Artemisia spicigera & $X$ axonopodis pv. vesicatoria & $100 \mu \mathrm{l} / \mathrm{ml}$ & - & Kotan et al., 2007 \\
\hline Tanacetum aucheranum & X. axonopodis pv. vesicatoria & $100 \mu \mathrm{l} / \mathrm{ml}$ & - & Kotan et al., 2007 \\
\hline Achillea millefolium & X. axonopodis pv. vesicatoria & $50 \mu \mathrm{l} / \mathrm{ml}$ & - & Kotan et al., 2007 \\
\hline Matricaria perforate & X. axonopodis pv. vesicatoria & $200 \mu \mathrm{l} / \mathrm{ml}$ & - & Kotan et al., 2007 \\
\hline Thymus spathulifolius & X. campestris-A235 & $500 \mu \mathrm{g} / \mathrm{ml}$ & - & Sokmen et al., 2004 \\
\hline Galium verum & X. axonopodis pv. vesicatoria & $600 \mu \mathrm{l} / \mathrm{ml}$ & - & Kotan et al., 2007 \\
\hline Tanacetum chilliophyllum & $X$. axonopodis pv. vesicatoria & $100 \mu \mathrm{l} / \mathrm{ml}$ & - & Kotan et al., 2007 \\
\hline Thymus sipyleus rosulans & X. axonopodis pv. vesicatoria & $200 \mu \mathrm{l} / \mathrm{ml}$ & - & Kotan et al., 2007 \\
\hline Thymus sipyleus & X. axonopodis pv. vesicatoria & $25 \mu \mathrm{l} / \mathrm{ml}$ & - & Kotan et al., 2007 \\
\hline Satureja hortensis & X. axonopodis pv. vesicatoria & $25 \mu \mathrm{l} / \mathrm{ml}$ & - & Kotan et al., 2007 \\
\hline
\end{tabular}


Table 1. Continued

\begin{tabular}{llllc}
\hline \hline \multicolumn{1}{c}{ EO derived from } & \multicolumn{1}{c}{ Bacteria } & MIC & MBC & Reference \\
\hline Melissa officinalis & X. axonopodis pv. vesicatoria & $200 \mu \mathrm{l} / \mathrm{ml}$ & - & Kotan et al., 2007 \\
Thymus canoviridis & X. axonopodis pv. vesicatoria & $200 \mu \mathrm{l} / \mathrm{ml}$ & - & Kotan et al., 2007 \\
Thymbra sintenisii & X. campestris pv. pruni & $600 \mathrm{ppm}$ & - & Biavati et al., 2004 \\
Cleistocalyx operculatus & X. campestris pv. campestris KC94-17 & $31.25 \mu \mathrm{g} / \mathrm{ml}$ & $62.5 \mu \mathrm{g} / \mathrm{ml}$ & Bajpai et al., 2010a \\
& X. campestris pv. vesicatoria YK93-4 & $62.5 \mu \mathrm{g} / \mathrm{ml}$ & $62.5 \mu \mathrm{g} / \mathrm{ml}$ & Bajpai et al., 2010a \\
& X. oryzae pv. oryzae KX019 & $31.25 \mu \mathrm{g} / \mathrm{ml}$ & $62.5 \mu \mathrm{g} / \mathrm{ml}$ & Bajpai et al., 2010a \\
& X. sp. SK12 & $125 \mu \mathrm{g} / \mathrm{ml}$ & $250 \mu \mathrm{g} / \mathrm{ml}$ & Bajpai et al., 2010a \\
Metasequoia glyptostroboides & X. campestris pv. campestris KC94-17 & $125 \mu \mathrm{g} / \mathrm{ml}$ & $125 \mu \mathrm{g} / \mathrm{ml}$ & Bajpai et al., 2010b \\
& X. campestris pv. vesicatoria YK93-4 & $250 \mu \mathrm{g} / \mathrm{ml}$ & $500 \mu \mathrm{g} / \mathrm{ml}$ & Bajpai et al., 2010b \\
& X. oryzae pv. oryzae KX019 & $125 \mu \mathrm{g} / \mathrm{ml}$ & $125 \mu \mathrm{g} / \mathrm{ml}$ & Bajpai et al., 2010b \\
& X. sp. SK12 & $250 \mu \mathrm{g} / \mathrm{ml}$ & $250 \mu \mathrm{g} / \mathrm{ml}$ & Bajpai et al., 2010b \\
Cuminum cyminum & X. campestris pv. phaseoli & $575 \mu \mathrm{g} / \mathrm{ml}$ & - & Iacobellis et al., 2005 \\
& X. campestris pv. phaseoli var. fuscans & $460 \mu \mathrm{g} / \mathrm{ml}$ & - & Iacobellis et al., 2005 \\
& X. campestris pv. vesicatoria & $345 \mu \mathrm{g} / \mathrm{ml}$ & - & Iacobellis et al., 2005 \\
& X. campestris pv. campestris & $920 \mu \mathrm{g} / \mathrm{ml}$ & - & Iacobellis et al., 2005 \\
& X. campestris pv. phaseoli & $170.2 \mu \mathrm{g} / \mathrm{ml}$ & - & Iacobellis et al., 2005 \\
Carum carvi & X. campestris pv. phaseoli var. fuscans & $455 \mu \mathrm{g} / \mathrm{ml}$ & - & Iacobellis et al., 2005 \\
& X. campestris pv. vesicatoria & $227.5 \mu \mathrm{g} / \mathrm{ml}$ & - & Iacobellis et al., 2005 \\
& X. campestris pv. campestris & $455 \mu \mathrm{g} / \mathrm{ml}$ & - & Iacobellis et al., 2005 \\
Satureja cuneifolia & X. campestris pv. pruni & $800 \mathrm{ppm}$ & - & Biavati et al., 2004 \\
\hline
\end{tabular}

MIC: Minimum inhibitory concentration; MBC: Minimum bactericidal concentration; EO: Essential oil.

tested pathogens. In this study, $X$. campestris $p v$. vesicatoria was found to be the most sensitive bacterial pathogen to the tested essential oils (Gyorgyi et al., 2004).

As reported previously, the in vivo trial conducted on greenhouse-grown oriental melon plants using the essential oil of $M$. glyptostroboides, the oil at the used concentrations exhibited potent antibacterial effect against $X$. campestris pv. vesicatoria YK93-4-XCV and X. sp. SK12 with 100\% disease suppression efficacy (Bajpai et al., 2010b). Although higher concentrations reflected higher antibacterial efficacy against the tested plant pathogens of Xanthomonas species, a lower concentration of M. glyptostroboides oil also exerted significant in vivo antibacterial effect against $X$. campestris pv. vesicatoria YK93-4-XCV and $X$. sp. SK12 with disease suppression efficacy of 65.21 and $72.29 \%$, respectively (Fig. 2). Earlier in vivo studies on the analysis of antibacterial effect of various essential oils showed that they had varying degree of antibacterial effect against different plant pathogenic bacteria (Hevesi et al., 2006).

In addition to this, another in vivo trial was conducted on greenhouse grown oriental melon plants against plant pathogenic bacteria of Xanthomonas species such as $X$. campestris pv. vesicatoria YK93-4 and X. sp. SK12 (Bajpai et al., 2010a). The essential oil of $C$. operculatus buds at the concentration of 2,000 and $1,000 \mu \mathrm{g} / \mathrm{ml}$ revealed potential antibacterial effect as $100 \%$ disease suppression efficiency against $X$. campestris pv. vesicatoria YK93-4 (causal agent of bacterial spot) and $X$. sp. SK12 (causing water-soaked lesions). A dose of $500 \mu \mathrm{g} / \mathrm{ml}$ concentration of the essential oil of $C$. operculatus buds also exhibited significant antibacterial efficacy against $X$. campestris pv. vesicatoria YK93-4 and $X$. sp. SK12 with their respective disease suppression efficiency of $72.8 \pm 2.9$ and $83.63 \pm 5.7 \%$ (Fig. 3). It was observed that higher essential oil concentrations of $C$. operculatus had strong antibacterial effect against the bacterial pathogenicity of $X$. campestris pv. vesicatoria YK93-4 and $X$. sp. SK12 and no bacterial disease symptoms (bacterial blight, bacterial spot, watersoaked lesions and twig dieback) were observed on the leaves of tested oriental melon plants caused by plant pathogenic bacteria of Xanthomonas species.

The potential use of essential oils extracted from Ociumum gratissimum and T. vulgaris was investigated for their ability to control seed infection of $X$. oryzae in naturally infected seeds using liquid assay (Nguefack et al., 2005). The essential oils applied significantly reduced the seed infection by $32 \%$ on three rice cultivars. The vigor of rice seedlings raised from the treated seeds was greater compared to the control. The treatment with essential oils reduced the total cell counts of Xanthomonas bacteria at a range of $92-97 \%$. Both essential oils also increased the germination capacity of the treated seeds with 13 to $23 \%$ 

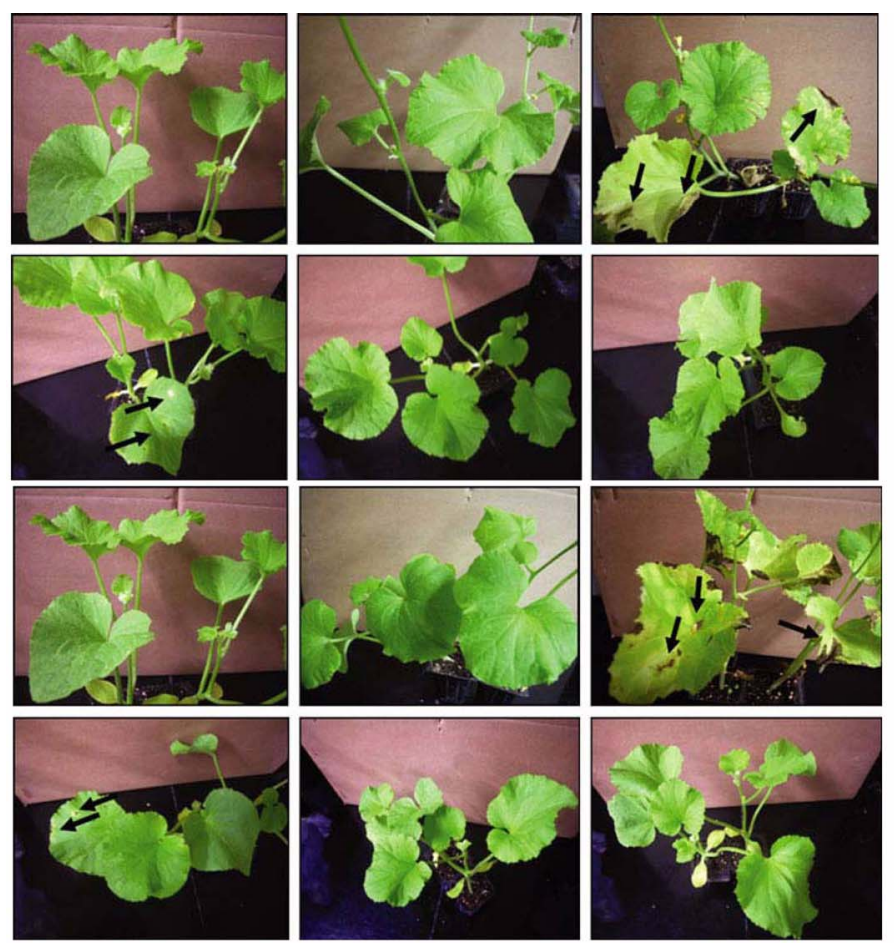

(i) Xanthomonas sp. SK12 inoculated on oriental melon plants

\section{(ii) Xanthomonas \\ campestris pv.} vesicatoria YK93-4$\mathrm{XCV}$ inoculated on oriental melon plants

Fig. 2. In vivo antibacterial effect of the essential oil of Metasequoia glyptostroboides against plant pathogenic bacteria of (i) Xanthomonas sp. SK12 and (ii) X. campestris pv. vesicatoria YK93-4-XCV on oriental melon plants. a. No treatment (normal control); b. treated with vehicle $(0.5 \%$ dimethylsulfoxide $+0.1 \%$ tween 80 in water $)$; c. treated with pathogen in vehicle; $d$, e, f. treated with a pathogen and different concentrations of essential oil (500, 1,000 and 2,000 $\mu \mathrm{g} / \mathrm{ml}$, respectively) in vehicle. Arrow shows disease symptoms.
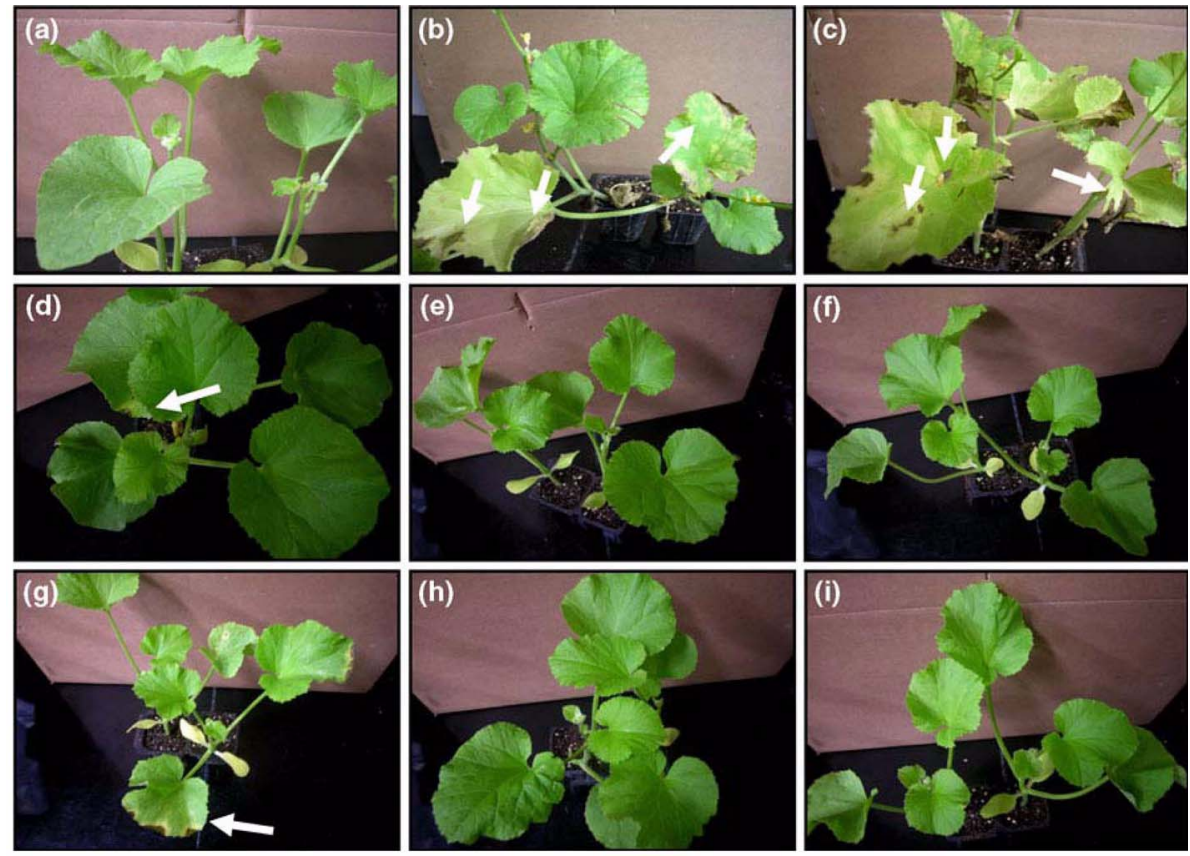

Fig. 3. In vivo antibacterial effect of the essential oil of Cleistocalyx operculatus buds against plant pathogenic bacterial strains of Xanthomonas sp. SK12 (Xsp SK12) and X campestris pv. vesicatoria YK93-4 (Xcv YK93-4) on greenhouse-grown oriental melon plants. a No treatment; b, c treated with pathogen strains Xsp SK12 and Xcv YK93-4 in vehicle (0.5\% DMSO + 0.1\% Tween 80 in water); d-f treated with pathogen (Xsp SK12) and different concentrations of the essential oil (500, 1,000 and 2,000 $\mu \mathrm{g} / \mathrm{ml}$, respectively) in the control; g-i treated with pathogen (Xcv YK93-4) and different concentrations of the essential oil $(500,1,000$ and 2,000 $\mu \mathrm{g} / \mathrm{ml}$, respectively) in the control. Arrow indicates the disease symptoms. 
(Nguefack et al., 2005).

Certain essential oils act in many ways on various types of disease complex and may be applied onto the important crop plants in the same way as other agricultural chemicals. These oils can be used as a leading factor in a wide range of activities against many plant pathogenic bacteria, where these pathogens have developed resistance against the specific bactericide (Cooksey, 1990; Minsavage et al., 1990). Among these pathogens, bacterial leaf blight caused by $X$. oryzae pv. oryzae has been reported most serious disease of rice in South-East Asia, particularly because the widespread cultivation of dwarf high-yielding cultivars (Ray and Sengupta, 1970). In our studies reported, it was confirmed that both essential oils derived from M. glyptostroboides and $C$. operculatus possessed great potential to strongly inhibit the growth of X. oryzae pv. oryzae KX019XCO along with other plant pathogenic bacteria tested (Bajpai et al., 2010a, b).

In another study conducted on plant pathogenic bacteria using the essential oil components, the terpenoid and phenylpropanoid derivatives showed considerable amount of antibacterial activity (Cantore et al., 2009). A reduced or negligible amount of antibacterial effect was exerted by those derivatives containing ketones, aldehydes, ethers, and ester functionalities as well as the remaining terpenoids. Eugenol emulsion treatments $(1-8 \mathrm{mg} / \mathrm{ml})$ on bean seeds bearing bacterial population about $2.6 \times 10^{6} \mathrm{cfu} / \mathrm{seed}$ of strain $X$. campestris pv. phaseoli var. fuscans evoked significant reduction of the bacterial population on bean seeds. In particular, eugenol at the concentration of $4 \mathrm{mg} / \mathrm{ml}$ disinfected the seeds bearing the bacterial population about $7.0 \times 10^{2} \mathrm{cfu} /$ seed or lower densities. However, after $72 \mathrm{~h}$, incubation treatments with 2,4 , and $8 \mathrm{mg} / \mathrm{ml}$ of eugenol caused germination reduction of only 3,7 and $16 \%$, respectively. The findings of this study indicated that essential oil component eugenol could be used as a potential agent in disinfection process of bean seeds caused by $X$. campestris pv. phaseoli var. fuscans. A literature description on the in vivo antibacterial efficacy of some selected plant essential oils against plant pathogenic bacteria of Xanthomonas species is summarized in Table 2.

Moreover, information on the antibacterial effects of plant-mediated oils is scant, these pathogens are responsible for serious economic losses in various parts of the world and, although control measures are available, they are of limited effectiveness (Kvillan and Scheffer, 1958; Munnecke, 1954). Although there are not so many researches available in the literature on the antibacterial efficacy of essential oils against plant pathogenic Xanthomonas species, hence, we made an effort to summarize the published data on the efficacy of essential oils against plant pathogenic bacteria of Xanthomonas species in vitro and in vivo systems.

Table 2. In vivo antibacterial activity of selected plant essential oils against plant pathogenic bacteria of Xanthomonas species

\begin{tabular}{|c|c|c|c|c|c|c|}
\hline $\begin{array}{l}\text { Plants, Fruits, } \\
\text { Vegetables }\end{array}$ & $\begin{array}{c}\text { Disease } \\
\text { type }\end{array}$ & $\begin{array}{l}\text { Origin plants } \\
\text { for the } \\
\text { essential oils }\end{array}$ & $\begin{array}{l}\text { Concentration } \\
\text { applied }\end{array}$ & $\begin{array}{l}\text { Bacterial } \\
\text { pathogens }\end{array}$ & Observations & References \\
\hline \multirow{4}{*}{ Melon plant } & Leaf spot & $\begin{array}{l}\text { Cleistocalyx } \\
\text { Operculatus }\end{array}$ & $\begin{array}{c}500 \text { to } \\
2,000 \mu \mathrm{g} / \mathrm{ml}\end{array}$ & $\begin{array}{l}\text { X. campestris } \\
\text { pv. vesicatoria } \\
\text { YK95-4 }\end{array}$ & $\begin{array}{l}100 \% \text { disease suppression efficacy at } \\
1,000 \text { and } 2,000 \mu \mathrm{g} / \mathrm{ml} \text { concentration, } \\
72.8 \% \text { disease suppression efficacy at } \\
500 \mu \mathrm{g} / \mathrm{ml} \text { concentration }\end{array}$ & $\begin{array}{l}\text { Bajpai } \\
\text { et al., 2010a }\end{array}$ \\
\hline & Leaf spot & $\begin{array}{l}\text { Cleistocalyx } \\
\text { Operculatus }\end{array}$ & $\begin{array}{c}500 \text { to } \\
2,000 \mu \mathrm{g} / \mathrm{ml}\end{array}$ & $X$. sp. SK12 & $\begin{array}{l}100 \% \text { disease suppression efficacy at } \\
1,000 \text { and } 2,000 \mu \mathrm{g} / \mathrm{ml} \text { concentration, } \\
83.6 \% \text { disease suppression efficacy at } \\
500 \mu \mathrm{g} / \mathrm{ml} \text { concentration }\end{array}$ & $\begin{array}{l}\text { Bajpai } \\
\text { et al., 2010a }\end{array}$ \\
\hline & Leaf spot & $\begin{array}{c}\text { Metasequoia } \\
\text { glyptostroboides }\end{array}$ & $\begin{array}{c}500 \text { to } \\
2,000 \mu \mathrm{g} / \mathrm{ml}\end{array}$ & $\begin{array}{l}\text { X. campestris } \\
\text { pv. vesicatoria } \\
\text { YK95-4 }\end{array}$ & $\begin{array}{l}100 \% \text { disease suppression efficacy at } \\
1,000 \text { and } 2,000 \mu \mathrm{g} / \mathrm{ml} \text { concentration, } \\
65.21 \% \text { disease suppression efficacy at } \\
500 \mu \mathrm{g} / \mathrm{ml} \text { concentration }\end{array}$ & $\begin{array}{l}\text { Bajpai } \\
\text { et al., } 2010 b\end{array}$ \\
\hline & Leaf spot & $\begin{array}{c}\text { Metasequoia } \\
\text { glyptostroboides }\end{array}$ & $\begin{array}{c}500 \text { to } \\
2,000 \mu \mathrm{g} / \mathrm{ml}\end{array}$ & $X$. sp. SK12 & $\begin{array}{l}100 \% \text { disease suppression efficacy at } \\
1,000 \text { and } 2,000 \mu \mathrm{g} / \mathrm{ml} \text { concentration, } \\
72.29 \% \text { disease suppression efficacy at } \\
500 \mu \mathrm{g} / \mathrm{ml} \text { concentration }\end{array}$ & $\begin{array}{l}\text { Bajpai } \\
\text { et al., 2010b }\end{array}$ \\
\hline \multirow{2}{*}{ Rice seed } & $\begin{array}{c}\text { Seed } \\
\text { infection }\end{array}$ & $\begin{array}{c}\text { Ociumum } \\
\text { gratissimum }\end{array}$ & $\begin{array}{l}\text { Slurry formulation } \\
\text { and liquid assay }\end{array}$ & X. oryzae & $\begin{array}{l}\text { Reduction in seed infection rate by } 32 \% \\
\text { and increased the germination capacity } \\
\text { by } 13 \text { to } 23 \% \text {. }\end{array}$ & $\begin{array}{l}\text { Nguefack } \\
\text { et al., } 2005\end{array}$ \\
\hline & $\begin{array}{c}\text { Seed } \\
\text { infection }\end{array}$ & $\begin{array}{l}\text { Thymus } \\
\text { vulgaris }\end{array}$ & $\begin{array}{l}\text { Slurry formulation } \\
\text { and liquid assay }\end{array}$ & X. oryzae & $\begin{array}{l}\text { Reduction in seed infection rate by } 32 \% \\
\text { and increased the germination capacity } \\
\text { by } 13 \text { to } 23 \% \text {. }\end{array}$ & $\begin{array}{l}\text { Nguefack } \\
\text { et al., } 2005\end{array}$ \\
\hline
\end{tabular}


Hence, as a result, work on alternative approaches such as essential oils to control these pathogens will be beneficial.

\section{Legal Aspects of the Use of Essential Oils}

The European Union (EU) and FDA are constantly producing the most valuable recommendations and laws on the issues of use of essential oils in various industries. A number of essential oils have been registered by European Commission and FDA for their use in food and agriculture industries to control harmful pathogenic microbes. The EU registered essential oils also appear on the 'Everything Added to Food in the US (EAFUS) list, which means that FDA has classified these substances as generally recognized as safe (GRAS) (Smoley, 1993). A fluctuation of microbial communities in relation to the release of essential oils by Lavandula officinalis was also observed and it was confirmed that the essential oils could be useful as potential bio-herbicides as an alternative strategy to the chemical remedy, suggesting the legal aspects of using essential oils in agriculture (Zanellato et al., 2009).

The flavourings registered are considered to present no risk to the health of the consumer and include amongst others allspice oil, anise oil, black pepper oil, caraway oil, cubeb oil, star anise oil and sweet bay. New flavourings may only be evaluated for registration after toxicological and metabolic studies have been carried out (Commission Decision of 23 February, 1999; Commission Regulation (EC) No $1565 / 2000$ of 18 July 2000 laying down the measures necessary for the adoption of an evaluation programme in application of Regulation (EC) No 2232/96 of the European Parliament and of the Council: Official Journal L180 19/07/2000, pp. 8-16. Commission Regulation (EC) No 1565/2000; Commission Regulation (EC) No. 622/ 2002 and Regulation (EC) No 2232/96), which could entail a considerable financial outlay.

In other countries if applied in agriculture as natural biopesticides, these essential oils might be treated as new and safe. Approval on essential oils as safe and natural biopesticides in agriculture would probably involve expensive safety and metabolic studies, the cost of which may be prohibitive. From a legislative point of view it would in those countries be economically more feasible to use a whole spice or herb or a whole essential oil as an ingredient than to use individual essential oil components (Smid and Gorris, 1999).

\section{Future Perspectives}

In a recent survey, essential oil-based aromatherapy has been successfully evaluated in agriculture as a natural pest management strategy to control the growth of harmful microbes in agriculture including plant pathogenic bacteria (Isaman, 2010). As we know that essential oils are generally recognized as safe, hence, there might be a high demand of essential oils in agriculture as aromatherapy to support the pest management system in agriculture. The most diverse and interesting area for the application of essential oils or their components is the inhibition of growth and reduction in numbers of the serious plant pathogenic bacteria such as Xanthomonas species. The delay of infection and improvement of plant growth promoting activities in agricultural products may also be interesting from a commercial point of view. It may be possible to use essential oils in agriculture if the presence of one or more synergists can produce the desired antibacterial effect at a concentration which does not produce undesirable changes.

The use of essential oils in consumer goods is expected to increase in the future due to the rise of 'green consumerism', which stimulates the use and development of products derived from plants (Tuley de Silva, 1996). This applies to not only the food and cosmetic sectors but also to agricultural products If essential oils were to be required in much greater volumes, bioengineering of their synthesis in plants could provide greater yields (Mahmoud and Croteau, 2002). International standardization of the composition of commercially available essential oils would be essential for safe and reliable applications Carson and Riley, 2001).

The action of essential oil components on proteins embedded in the cytoplasmic membrane and on phospholipids in the membrane is not yet fully identified and is a focal area for future research. Further elucidation of these mechanisms would provide insights that may prove useful for technological applications. Interactions between essential oils and their components need to be investigated. Synergistic effects could be exploited so as to maximize the antibacterial activity of essential oils and to minimize the concentrations of synthetic pesticide required to achieve a particular antibacterial effect. Antagonism between essential oils and their ingredients is undesirable and research is needed so it can be avoided in practical applications. Possible secondary or indirect consequences of the use of essential oils would need to be explored; the addition of essential oils might have any disadvantageous effects on the safety of the economically important plants in agriculture, such as influencing the stress tolerance of plant pathogens.

\section{Conclusion}

Xanthomonas bacteria are one of the major sources of the plant diseases in agriculture. Agricultural products related to fruits, vegetables and crops are among the major Xanthomonas carriers in the agricultural system. Reducing Xanthomonas infection in economically important crop 
plants and food products requires a complete approach that includes the entire integrated operation. Therefore, in order to obtain a substantial reduction of harmful pathogen loads in agriculture, the application of a combination of intervention strategies is required. A number of essential oils and several of their individual components exhibit antibacterial activity against plant pathogenic bacteria in vitro and, in agricultural system. Undesirable plant disease infections can be limited by careful selection of essential oil according to the type of plant. If the active substances are to be applied in the agricultural practices in greater concentrations, safety studies may be necessary. Based on the above literature, it can be concluded that plant-mediated essential oils could become alternative industrial products to synthetic bactericides for applying in agriculture industry to control severe bacterial diseases caused by Xanthomonas species. In fact, the development of natural antimicrobials would help to decrease the negative impact of synthetic agents, such as residues, resistance and environmental pollution. In this respect, essential oils as natural bio-pesticides may be effective, selective, biodegradable and less toxic to environment as well as to food and agriculture industries.

\section{Acknowledgement}

This work was carried out with support of the "Cooperative Research Program for Agriculture Science \& Technology Development (Project No. PJ0075122011)" Rural Development Administration, Republic of Korea. Sora Kang was supported by the Research Assistant Grant (208-A-251178) from Yeungnam University.

\section{References}

Agrios, G. N. 2004. Plant Pathology. 5th ed. Academic Press, London.

Akhtar, M. A., Rahber-Bhatti, M. H. and Aslam, M. 1995 Antibacterial activity of plant diffusate against Xanthomonas campestris pv. citri. Int. J. Pest Manage. 43:149-153.

Angioni, A., Barra, A., Cereti, E., Barile, D., Coïsson, J. D., Arlorio, M., Dessi, S., Coroneo, V. and Cabras, P. 2004. Chemical composition, plant genetic differences, antimicrobial and antifungal activity investigation of the essential oil of Rosmarinus officinalis L. J. Agric. Food Chem. 52:3530-3535.

Araujo, J. S. P., Robbs, C. F. and Ribeiro, R. L. D. 2003. Manejo integrado de fitobacterioses de importancia economica no Brasil. Parte 1. Rev. Ann. Pathol. Plantas 11:107-131.

Araujo, A. E. and Siqueri, F. V. 1999. Evaluation of the efficiency of the use of copper oxychloride and a mixture of oxytetracycline + streptomycin sulfate to control angular leaf spot in cotton. Comun. Tecn. Embr. Algo. 105:3.

Awasa Agricultural Research Center (ARCP). 2000. Progress Report 1999-2000.
Bajpai, V. K., Dung, N. T., Suh, H. J. and Kang, S. C. 2010a. Antibacterial activity of essential oil and extracts of Cleistocalyx operculatus buds against the bacteria of Xanthomonas spp. J. Am. Oil Chem. Soc. 87:1341-1349.

Bajpai, V. K., Cho, M. J. and Kang, S. C. 2010b. Control of plant pathogenic bacteria of Xanthomonas spp. by the essential oil and extracts of Metasequoia glyptostroboides Miki ex $\mathrm{Hu}$ in vitro and in vivo. J. Phytopathol. 158:479-486.

Bajpai, V. K., Rahman, A., Choi, U. K., Youn, S. J. and Kang, S. C. 2007. Inhibitory parameters of the essential oil and various extracts of Metasequoia glyptostroboides Miki ex $\mathrm{Hu}$ to reduce food spoilage and food-borne pathogens. Food Chem. 105:1061-1066.

Balestra, G. M., Heydari, A., Ceccarelli D., Ovidi, E. and Quattrucci, A. 2009. Antibacterial effect of Allium sativum and Ficus carica extracts on tomato bacterial pathogens. Crop Prot. 28:807-811.

Basim, E. and Basim, H. 2003. Antibacterial activity of Rosa damascene essential oil. Fitoterapia 74:394-396.

Batlle, R., Colmsjo, A. and Nilsson, U. 2001. Determination of gaseous toluene diisocyanate by use of solid-phase microextraction with on-fiber derivatisation. Fresenius'J. Anal. Chem. 369:524-529.

Bauer, K. and Garbe, D. 1985. Common Fragrance and Flavor Materials. Preparation, Properties and Uses. VCH Verlagsgesellschaft, Weinheim, p. 213.

Biavati, B., Ozcan, M. and Piccaglia, R. 2004. Composition and antimicrobial properties of Satureja cuneifolia Ten. and Thymbra sintenisii Bornm. Et Aznav. subsp. Isaurica P.H. Davis essential oils. Ann. Microbiol. 54:393-401.

Boyle, W. 1955. Spices and essential oils as preservatives. Am. Perfu. Essen. Oil Rev. 66:25-28.

Burt, S. A. 2004. Essential oils: their antibacterial properties and potential applications in foods-a review. Int. J. Food Microbiol. 94:223-253.

Burt, S. A. and Reinders, R. D. 2003. Antimicrobial activity selected plant essential oils against Escherichia coli O157:H7. Lett. Appl. Microbiol. 36:162-167.

Caccioni, D. R. L., Guizzardi, M., Biondi, D. M., Renda, A. and Ruberto, G. 1998. Relationship between volatile components of citrus fruit essential oils and antimicrobial action on Penicillium digitatum and Penicillium italicum. Int. J. Food Microbiol. 43:73-79.

Cantore, P. I., Shanmugaiah, V. and Iacobellis, N. S. 2009. Antibacterial activity of essential oil components and their potential use in seed disinfection. J. Agric. Food Chem. 57:94549461.

Carson, C. F., Mee, B. J. and Riley, T. V. 2002. Mechanism of action of Melaleuca alternifolia (tea tree) oil on Staphylococcus aureus determined by time-kill, lysis, leakage and salt tolerance assays and electron microscopy. Antimicrob. Agent Chemother. 46:1914-1920.

Carson, C. F. and Riley, T. V. 1995. Antimicrobial activity of the major components of the essential oil of Melaleuca alternifolia. J. Appl. Bacteriol. 78:264-269.

Carson, C. F. and Riley, T. V. 2001. Safety, efficacy and prove- 
nance of tea tree (Melaleuca alternifolia) oil. Cont. Dermat. 45:65-67.

Cavalcanti, F. R., Resende, M. L. V., Carvalho, C. P. S., Silveira, J. A. G. and Oliveira, J. T. A. 2006. Induced defence responses and protective effects on tomato against Xanthomonas vesicatoria by an aqueous extract from Solanum lycocarpum infected with Crinipellis perniciosa. Biol. Cont. 39:408-417.

Chen, Y. and Pawliszyn, J. 2003. Time-weighted average passive sampling with a solid-phase microextraction device. Anal. Chem. 75:2004-2010.

Claflin, L. 2003. Control of Pseudomonas syringae pathovars. In Pseudomonas syringae and Related Pathogens; Iacobellis, et al., Eds.; Kluwer Academic Publishers: Dordrecht, The Netherlands, pp. 423-430.

Conner, D. E. 1993. Naturally occurring compounds. In: Davidson, P. \& Branen, A. L. (Eds.). Antimicrobials in foods. New York, Marcel Dekker, Inc., pp. 441-468.

Cooksey, D. A. 1990. Genetics of bactericide resistance in plant pathogenic bacteria. Annu. Rev. Phytopathol. 28:201-219.

Cox, S. D., Mann, C. M., Markham, J. L., Bell, H. C., Gustafson, J. E., Warmington, J. R. and Wyllie, S. G. 2000. The mode of antimicrobial action of essential oil of Melaleuca alternifola (tea tree oil). J. Appl. Microbiol. 88:170-175.

Csizinszky, A. A., Civerolo, E. L. and Jones, J. B. 1993. Inactivation of Xanthomonas campestris pvs. in vitro with plant extracts. First world congress on medicinal and aromatic plants for human welfare (WOCMAP), Maastricht, Netherlands, 19-25 July 1992. Acta Hortic. 331:301-305.

Dagnachew, Y. and Bradbury, J. F. 1968. Bacterial wilt of Enset (Enset ventricosum) incited by Xanthomonas campestris sp. Phytopathology 59:111-112.

Dagnachew, Y. and Bradbury, J. F. 1974. A note on wilt of banana caused by enset wilt organism. Xanthomonas campestris. East Afr. Agric. Fores. J. 40:111-114.

Dayakar, B. V. and Gnanamanickam, S. S. 1996. Biochemical and pathogenic variation in strains of Xanthomonas campestris pv. mangiferaeindicae from Southern India. Indian Phytopathol. 49:227-233.

Deans, S. G. and Ritchie, G. 1987. Antibacterial properties of plant essential oils. Int. J. Food Microbiol. 5:165-180.

Deena, M. J. and Thoppil, J. E. 2000. Antimicrobial activity of the essential oil of Lantana camara. Fitoterapia 71:453-455.

Dekker, J. 1987. The risks for development of fungicide resistance a worldwide problem. In: Magallona ED. (ed) Proceedings the $11^{\text {th }}$ International Congress of Plant Protection, 5-7 October. Manila, Philippines, pp 318-321.

Delaquis, P. J., Stanich, K., Girard, B. and Mazza, G. 2002. Antimicrobial activity of individual and mixed fractions of dill, cilantro, coriander and eucalyptus essential oils. Int. J. Food Microbiol. 74:101-109.

Denyer, S. P. and Hugo, W. B. 1991. Biocide-induced damage to the bacterial cytoplasmic membrane. In: Denyer, S.P. and Hugo, W.B., Editors, 1991. Mechanisms of Action of Chemical Biocides. The Society for Applied Bacteriology, Technical Series No 27, Oxford Blackwell Scientific Publication, Oxford, pp. 171-188.
Dereje, A. 1981. Studies on bacterial wilt of enset. Paper presented at the $13^{\text {th }}$ National Crop Improvement Conference. Addis Ababa, Ethiopia. 23-25 March 1981. IAR, Ethiopia.

Dereje, A. 1985. Studies on the bacterial wilt of enset (Ensete ventricosum) and prospects for its control. Ethiop. J. Agric. Sci. 7:1-14.

Didry, N., Dubreuil, L. and Pinkas, M. 1993. Activite antimicrobienne du thymol, du carvacrol et de l'aldehyde cinnamique seuls ou associes (Antibacterial activity of thymol, carvacrol, and cinnalmaldehyde singly or in combinations). Pharmazie 48:301-308.

Dorman, H. J. D. and Deans, S. G. 2000. Antimicrobial agents from plants: antibacterial activity of plant volatile oils. J. Appl. Microbiol. 88:308-316.

Dung, N. T., Kim, J. M. and Kang, S. C. 2008. Chemical composition, antimicrobial and antioxidant activities of the essential oil and the ethanol extract of Cleistocalyx operculatus (Roxb.) Merr and Perry buds. Food Chem.Toxicol. 46:3632-3639.

Farag, R. S., Daw, Z. Y., Hewedi, F. M. and El-Baroty, G. S. A. 1989. Antimicrobial activity of some Egyptian spice essential oils. J. Food Prot. 52:665-667.

Franco, O. L., Murad, A. M., Leite, J. R., Mendes, P. A., Prates, M. V. and Bloch, C. 2006. Identification of a cowpea gammathionin with bactericidal activity. FEBS J. 273:3489-3497.

Gabriel, D. W. and De Feyter, R. 1992. RFLP analyses and gene tagging for bacterial identification and taxonomy. In: Molecular Plant Pathology. Vol.1, A Practical Approach. (S.J. Gurr, M.J. McPherson and D.J. Bowles, eds). IRL Press, Oxford. pp. 51-66.

Gan-Mor, S. and Matthews, G. A. 2003. Recent developments in sprayers for application of bio-pesticides - An Overview. Bios. Eng. 84:119-125.

Gent, D. H. and Schwartz, H. F. 2005. Management of Xanthomonas leaf blight of onion with a plant activator, biological control agents, and copper bactericides. Plant Dis. 89:631-639.

Guenther, E. 1948. The Essential Oils. D. Van Nostrand, New York. USA.

Gustafson, J. E., Liew, Y. C., Chew, S., Markham, J. L., Bell, H. C., Wyllie, S. G. and Warmington, J. R. (1998. Effects of tea tree oil on Escherichia coli. Lett. Appl. Microbiol. 26:194198.

Gyorgyi Horváth, G., Szabo, L. G., Lemberkovics, E., Botz, L. and Kocsis, B. 2004. Characterization and TLC-bioautographic detection of essential oils from some Thymus taxa. Determination of the activity of the oils and their components against plant pathogenic bacteria. J. Planar Chromatogr. Modern TLC. 17:300-304.

Hayward, A. C. 1993. The host of Xanthomonas. In: Xanthomonas; pp. 51-54. J.G. Swings and E.L. Civerolo (eds.); Chapman \& Hall, London, United Kingdom.

Helander, I. M., Alakomi, H. L., Latva-Kala, K., Mattila-Sandholm, T., Pol, I., Smid, E. J., Gorris, L. G. M. and von Wright, A. 1998. Characterization of the action of selected essential oil components on Gram-negative bacteria. J. Agric. Food Chem. 46:3590-3595.

Hevesi, M., Al-arabi, K., Gondor, M., Papp, J., Honty, K., Kasa, 
K. and Toth, M. 2006. Development of eco-friendly strategies for the control of fire blight in Hungry. International Society for Horticultural Science, ISHS Acta Horticulturae 704: X International Workshop on Fire Blight, Bologna, Italy.

Holley, R. A. and Patel, D. 2005. Improvement in shelf-life and safety of perishable foods by plant essential oils and smoke antimicrobials. Food Microbiol. 22:273-292.

Hugouvieux, V., Barber, C. E. and Daniels, M. J. 1998. Entry of Xanthomonas campestris pv. campestris into hydathodes of Arabidopsis thaliana leaves: a system for studying early infection events in bacterial pathogenesis. Mol. Plant-Microbe Interact. 11:537-543.

Hwang, I. and. Lim, S. M. 1998. Pathogenic variability in isolates of Xanthomonas campestris pv. glycines. Kor. J. Plant Pathol. 14:19-22.

Iacobellis, N. S., Cantore, P. L., Capasso, F. and Senatores, F. 2005. Antibacterial activity of Cuminum cyminum L. and Carum carvi L. essential oils. J. Agric. Food Chem. 53:57-61.

Ilsley, S., Miller, H., Greathead, H. and Kamel, C. 2002. Herbal sow diets boost pre-weaning growth. Pig Prog. 18:8-10.

Isman, M. B. 2010. Aromatherapy for pest management? Pesticide based on plant essential oils for agriculture, industry and as consumer. University of British Columbia, Vancouver, Canada.

Ji, G. H., Wei, L. F., He, Y. Q., Wu, Y. P. and Bai, X. H. 2008. Biological control of rice bacterial blight by Lysobacter antibioticus strain 13-1. Biol. Cont. 45:288-296.

Juliano, C., Mattana, A. and Usai, M. 2000. Composition and in vitro antimicrobial activity of the essential oil of Thymus herba-barona Loisel growing wild in Sardinia. J. Essen. Oil Res. 12:516-522.

Juven, B. J., Kanner, J., Schved, F. and Weisslowicz, H. 1994. Factors that interact with the antibacterial action of thyme essential oil and its active constituents. J. Appl. Bacteriol. 76:626-631.

Khare, U. K. and Khare, M. N. 1995. Studies on survival of Xanthomonas campestris pv. glycines. Indian Phytopathol. 48:180-181.

Kim, J., Marshall, M. R. and Wei, C. I. 1995. Antibacterial activity of some essential oil components against five foodborne pathogens. J. Agric. Food Chem. 43:2839-2845.

Kivillan, A. and Scheffer, R. P. 1958. Factors affecting development of bacterial stem rot of Pelargonium. Phytopathology 48:185-191.

Knobloch, K., Weigand, H., Weis, N., Schwarm, H. M. and Vigenschow, H. 1986. Action of terpenoids on energy metabolism. In: Brunke, E.J., Editor, 1986. Progress in Essential Oil Research: 16th International Symposium on Essential Oils, De Gruyter, Berlin, pp. 429-445.

Knobloch, K., Pauli, A., Iberl, B., Weigand, H. and Weis, N. 1989. Antibacterial and antifungal properties of essential oil components. J. Essen. Oil Res. 1:119-128.

Kotan, R., Dadasoglu, F., Kordali, S. Cakır, A., Dikbas, N. and Cakmakc1, R. 2007. Antibacterial activity of essential oils extracted from some medicinal plants, carvacrol and thymol on Xanthomonas axonopodis pv. vesicatoria (Doidge) Dye causes bacterial spot disease on pepper and tomato. J. Agric. Technol. 12:299-306.

Lambert, R. J. W., Skandamis, P. N., Coote, P. and Nychas, G. J. E. 2001. A study of the minimum inhibitory concentration and mode of action of oregano essential oil, thymol and carvacrol. J. Appl. Microbiol. 91:453-462.

Lenka, S. and Ram, S. 1997. A note on the efficacy in vivo of various antibiotics and fungicide chemicals against Xanthomonas campestris pv. campestris causing black rot of cauliflower. Ori. J. Hortic. 25:90-92.

Leyns, F., De Cleene, M., Swings, J. and De Ley, J. 1984. Bot. Rev. 50:308-356.

Longbottom, C. J., Carson, C. F., Hammer, K. A., Mee, B. J. and Riley, T. V. 2004. Tolerance of Pseudomonas aeruginosa to Melaleuca alternifolia (tea tree) oil is associated with the outer membrane and energy-dependent cellular processes. J. Antimicrob. Chemother. 54:386-392.

Lopez, P., Sanchez, C., Battle, R. and Nerin, C. 2005. Solid- and vapor-phase antimicrobial activities of six essential oils: susceptibility of selected foodborne bacterial and fungal strains. $J$. Agric. Food Chem. 53:6939-6946.

Mahmoud, S. S. and Croteau, R. B. 2002. Strategies for transgenic manipulation of monoterpene biosynthesis in plants. Trends Plant Sci. 7:366-373.

Maiti, D., Kole, R. C. and Sen, C. 1985. Antimicrobial efficacy of some essential oils. J. Plant Dis. Prot. 92:64-68.

Manners, J. G. 1993. Principles of Plant Pathology. 2nd ed. Cambridge University Press.

Maruzzella, J. C., Reine, S., Solat, H. and Zeitlin, H. 1963. The action of essential oils on phytopathogenic bacteria. Plant Dis. Rep. 47:23-26.

Massomo, S. M. S., Mortensen, C. N., Mabagala, R. B., Newman, M. A. and Hockenhull, J. 2004. Biological control of black rot (Xanthomonas campestris pv. campestris) of cabbage in Tanzania with Bacillus strains. J. Phytopathol. 152:98-195.

McManus, P. S., Stockwell, V. O., Sundin, G. W. and Jones, A. L. 2002. Antibiotic use in plant agriculture. Annu. Rev. Phytopathol. 40:443-465.

Mejlholm, O. and Dalgaard, P. 2002. Antimicrobial effect of essential oils on the seafood spoilage micro-organism Photobacterium phosphoreum in liquid media and fish products. Lett. Appl. Microbiol. 34:27-31.

Minsavage, G. V., Canteros, B. I. and Stall, R. E. 1990. Plasmidmediated resistance to streptomycin in Xanthomonas campestris pv. vesicatoria. Phytopathology 80:719-723.

Miyazawa, M., Maehara, T. and Kurose, K. 2002. Composition of the essential oil from the leaves of Eruca sativa. Flavour Fragr. J. 17:187-190.

Montesinos, E. 2007. Antimicrobial peptides and plant disease control. FEMS Microbiol. Lett. 270:1-11.

Morris, J. A., Khettry, A. and Seitz, E. W. 1979. Antimicrobial activity of aroma chemicals and essential oils. J. Am. Oil Chem. Soc. 56:595-603.

Mourey, A. and Canillac, N. 2002. Anti-Listeria monocytogenes activity of essential oils components of conifers. Food Control 13: 289-292. 
Munnecke, E. 1954. Bacterial stem rot and leaf spot of Pelargonium. Phytopathology 33:626-632.

Nguefack, J., Somda, I., Mortensen, C. N. and Amvam Zollo, P. H. 2005. Evaluation of five essential oils from aromatic plants of Cameroon for controlling seed-borne bacteria of rice (Oryza sativa L.). Seed Sci. Technol. 33:397-407.

Norman, D. J., Chase, A. R., Stall, R. E. and Jones, J. B. 1999. Heterogenity of Xanthomonas campestris pv. hederae strains from araliaceous hosts. Phytopathology 89:646-652.

Oosterhaven, K., Poolman, B. and Smid, E. J. 1995. S-carvone as a natural potato sprout inhibiting, fungistatic and bacteristatic compound. Ind. Crop. Prod. 4:23-31.

Ornek, H., Aysan, Y., Mirik, M. and Sahin F. 2007. First report of bacterial leaf spot caused by Xanthomonas axonopodis pv. begoniae, on begonia in Turkey. Plant Pathol. 56:347-352.

Oussalah, M., Caillet, S. and Lacroix, M. 2006. Mechanism of action of Spanish oregano, Chinese cinnamon, and savory oils against cell membrane and walls of Escherichia coli O157:H7 and Listeria monocytogenes, J. Food Prot. 69:1046-1055.

Ozturk, S. and Ercisli, S. 2007. Antibacterial activity and chemical constitutions of Ziziphora clinopodioides. Food Cont. 18:535-540.

Paranagama, P. A., Abeysekera, K. H. T., Abeywickrama, K. and Nugaliyadd, L. 2003. Fungicidal and anti-aflatoxigenic effects of the essential oil of Cymbopogon citratus (DC.) Stapf. (lemongrass) against Aspergillus flavus Link isolated from stored rice. Lett. Appl. Microbiol. 37:86-90.

Paster, N., Menasherov, M., Ravid, U. and Juven, B. 1995. Antifungal activity of oregano and thyme essential oils applied as fumigants against fungi attacking stored grain. J. Food Prot. 58:81-85.

Patil, M. R. and Ghoderao, B. N. 1997. Evaluation of Some medicinal and aromatic plants against cotton bacterial blight infection. PKV Res. J. 21:179.

Pichersky, E., Noel, J. P. and Dudareva, N. 2006. Biosynthesis of plant volatiles: nature's diversity and ingenuity. Science, 311, 808-811.

Pruvost, O., Couteau, A., Perrier, X. and Luisetti, J. 1998. Phenotypic diversity of Xanthomonas sp. mangiferaeindicae. J. Appl. Microbiol. 84:115-124.

Quimio, J. A. and Mesfin, T. 1996. Diseases of Enset. In: Ensetbased Sustainable agriculture in Ethiopia (Tsedeke Abate, Clifton Hiebsch and Steve Brandt eds.). Proceedings of the First international workshop on Enset. Dec 13-21 1993. IAR, Addis Ababa, Ethiopia. pp.188-203.

Rasooli, I., Rezaei, M. B. and Allameh, A. 2006. Ultrastructural studies on antimicrobial efficacy of thyme essential oils on Listeria monocytogenes. Int. J. Inf. Dis. 10:236-241.

Raybaudi-Massilia, R. M., Mosqueda-Melgar, J. and Martín-Belloso, O. 2006. Antimicrobial activity of essential oils on Salmonella Enteritidis, Escherichia coli, and Listeria innocua in fruit Juices. J. Food Prot. 69:1579-1586.

Ray, P. R. and Sengupta, T. K. 1970. A study on the extent of loss in yield in rice due to bacterial blight. Indian Phytopathol. 23:713-714.

Restrepo, S., Velez, C. M. and Verdier, V. 2000. Measuring the genetic diversity of Xanthomonas axonopodis pv. manihotis within different fields in Colombia. Phytopathology 90:683690.

Rodriguez, H., Aguilar, L. and LaO, M. 1997. Variations in xanthan production by antibiotic-resistant mutants of Xanthomonas campestris. Appl. Microbiol. Biotechnol. 48:626-629.

Salamci, E., Kordali, S., Kotan, R., Cakır, A. and Kaya, Y. 2007. Chemical compositions, antimicrobial and herbicidal effects of essential oils isolated from Turkish Tanacetum aucheranum and Tanacetum chiliophyllum var. chiliophyllum. Biochem. Syst. Ecol. 35:569-581.

Salgueiro, L. R., Vila, R., Tomi, F., Figueiredo, A. C., Barroso, J. G. and Canigueral, S. 1997. Variability of essential oils of Thymus caespititius from Portugal. Phytochemistry 45:307-311.

Satish, S., Raveesha, K. A. and Janardhana, G. R. 1999. Antibacterial activity of plant extracts on phytopathogenic Xanthomonas campestris pathovars. Lett. App. Microbiol. 28:145147.

Savary, S., Teng, P. S., Willocquet, L. and Nutter, F. W. 2006. Quantification and modeling of crop losses: a review of purposes. Annu. Rev. Phytopathol. 44:89-112.

Shelef, L. A. 1983. Antimicrobial effects of spices. J. Food Safety 6:29-44.

Skkema, J., De Bont, J. A. M. and Poolman, B. 1995. Mechanisms of membrane toxicity of hydrocarbons. Microbiol. Rev. 59:201-222.

Skandamis, P. N. and Nychas, G. J. E. 2001. Effect of oregano essential oil on microbiological and physico-chemical attributes of minced meat stored in air and modified atmospheres. J. Appl. Microbiol. 91:1011-1022.

Smid, E. J. and Gorris, L. G. M. 1999. Natural antimicrobials for food preservation. In: Rahman, M.S. (Ed.), Handbook of Food Preservation. Marcel Dekker, New York, pp. 285-308.

Smoley, C. K. 1993. U.S. Food and Drug Administration. Everything Added to Food in the United States. CRC Press, Inc., Boca Raton, FL.

Sokmen, A., Gulluce, M., Askin Akpulat, H., Daferera, D., Tepe, B., Polissiou, M., Sokmen, M. and Sahin, F. 2004. The in vitro antimicrobial and antioxidant activities of the essential oils and methanol extracts of endemic Thymus spathulifolius. Food Cont. 15:627-634.

Spring, A., Hiebsch, C., Endale, T. and Gizachew, W. M. 1996. Enset needs assessment project phase I Report. Awasa, Ethiopia.

Sugimori, M. H. and De-Oliveira, A. R. 1994. Serological characterization of white pathovars of Xanthomonas campestris. Summa Phytopathol. 20:168-170.

Talwar, M., Kumar, P. and Saxena, S. C. 1996. Evaluation of chemicals including antibiotics against Xanthomonas campestris Pv. mangiferaeindicae, the bacterial canker pathogen of mango. Adv. Plant Sci. 9:235-237.

Thammaiah, N., Khan, A. and John, E. 1995. Effect of extract from Adhatoda zeylanica on Xanthomonas campestris pv. viginicola causing bacterial blight of cowpea. Adv. Agric. Res. India 4:109-117.

Thaveechai, N., Leksomboon, C., Kositratana, W., Paradornut- 
wat, A. and Rojanaridpiched, C. 1993. Survival of Xanthomonas campestris pv. manihotis under natural field conditions. Kasetsart J. Nat. Sci. 27:25-32.

Tobias, A., Lehoczki-Tornai, J., Szalai, Z., Csambalik, L. and Radics, L. 2007. Effect of different treatments to bacterial canker (Clavibacter michiganensis subsp. michiganensis), bacterial speck (Pseudomonas syringae pv. tomato) in tomato, and bacterial spot (Xanthomonas campestris pv. vesicatoria) in pepper. Int. J. Horti. Sci. 13:49-53.

Tuley de Silva, K. 1996. A Manual on the Essential Oil Industry. (Ed.), United Nations Industrial Development Organization, Vienna.

Ultee, A., Bennink, M. H. J. and Moezelaar, R. 2002. The phenolic hydroxyl group of carvacrol is essential for action against the food-borne pathogen Bacillus cereus. Appl. Environ. Microbiol. 68:1561-1568.

Van Welie, R. T. H. 1997. Alle cosmetica ingrediënten en hun functies. Nederlandse Cosmetica Vereniging, Nieuwegein, $p$. 126.

Van de Braak, S. A. A. J. and Leijten, G. C. J. J. 1999. Essential Oils and Oleoresins: A Survey in the Netherlands and other Major Markets in the European Union. CBI, Centre for the Promotion of Imports from Developing Countries, Rotterdam, p. 116.
Van Krimpen, M. M. and Binnendijk, G. P. 2001. RopadiarR as alternative for antimicrobial growth promoter in diets of weanling pigs. Lelystad, Praktijkonderzoek Veehouderij, p. 14.

Vasinauskiene, M., Radusiene, J., Zitikaite, I. and Surviliene E. 2006. Antibacterial activities of essential oil from aromatic and medicinal plants against growth of phytopathogenic bacteria. Agro. Res. 4:437-440.

Veracruz, C. M., Ardales, E. Y., Skinner, D. Z., Talag, J., Nelson, R. J., Louws, F. J., Leung, H., Mew, T. W. and Leach, J. E. 1996. Measurement of haplotypic variation in Xanthomonas oryzae pv. oryzae within a single field by rep-PCR and RFLP analyses. Phytopathology 86:1352-1359.

Wendakoon, C. N. and Sakaguchi, M. 1995. Inhibition of amino acid decarboxylase activity of Enterobacter aerogenes by active components in spices. J. Food Prot. 58:280-283.

Wells, J. M., Liao, C. and Hotchkiss, A. T. 1998. In vitro inhibition of soft-rotting bacteria by EDTA and nisin and in vivo response on inoculated fresh cut carrots. Plant Dis. 82:491495.

Zanellato, M., Masciarelli, E., Casorri, L., Boccia, P., Sturchio, E., Pezzella, M., Cavalieri, A. and Caporali, F. 2009. The essential oils in agriculture as an alternative strategy to herbicides: a case study. Int. J. Environ. Health 3:198-213. 